\title{
The International Rule of Law and Killing in War
}

What can institutional analysis tell us about global justice? Many philosophers seem to think that all institutional features are contingent and thus either irrelevant or only tangentially relevant for discussions regarding what justice requires. Even among those who accept the claim that theories of global justice need, so as to do their work well, to reference institutional arrangements, there is still a widely held belief that institutional structures can be almost infinitely bent to fit the notions of justice developed independently of those same structures. ${ }^{1}$ I believe, and set out to show, that this view is mistaken. In fact, I believe that some of the time what justice requires of us in the global arena can only be meaningfully answered by grounding such answers in the necessary institutional structures available for the pursuit of global justice. ${ }^{2}$

The primary aim of this paper is to suggest an appropriate place for the institution of international law in discussions of global justice. I argue that the necessary features of the institution of international law can and should be used to reject some and accept other principles of global justice. The necessary features of international law I start from are the rule of law conditions. While I am fully aware that among most legal theorists the term "necessary features" invokes both much more and much less than simply the rule of law conditions, I find this term to be appropriate, in this context, for referring to features that are necessary for international law to be internally coherent and accomplish its aim of guiding human (and state) behavior.

The question of whether and how the structure and processes of inter-

\footnotetext{
${ }^{1}$ Those that pay attention to institutional analysis at least to some extent include Christian Barry and Thomas W. Pogge (eds.), Global Institutions and Responsibilities: Achieving Global Justice (Oxford: Blackwell Publishers, 2005); Allen Buchanan, "Institutionalizing the Just War,” Philosophy \& Public Affairs 34 (2006): 2-38; Allen Buchanan and Robert O. Keohane, "The Legitimacy of Global Governance Institutions," Ethics and International Affairs 20 (2006): 405-37; John Rawls, Justice as Fairness: A Restatement, ed. Erin Kelly (Cambridge, Mass.: Harvard University Press, 2001).

${ }^{2}$ By "global justice" I mean a principle of behavior for global institutions and/or global society as a whole via institutions.
}

(C) Copyright 2012 by Social Theory and Practice, Vol. 38, No. 3 (July 2012) 
national law limit the actions that can be justly performed in the international arena can be separated into two further questions. First, is there a reason to think that some proposed individual principle of global justice is necessarily incompatible with international law? Second, does that give us a reason to think that that proposed principle is wrong, that is, that we (global society) ought not to act in accord with it? I will argue that some of the time the answer to both of these questions is "yes." If we can, without too much controversy, develop a set of conditions necessary for international law and develop an analysis of international law based on those necessary conditions, we can answer the first question. If we can give a principled account of which types of solutions to global justice problems require compatibility with international law, we have answered the second of the two questions. Together these two answers can help us in narrowing not simply the field of policy options, but in fact the field of philosophical and theoretical options.

In section 1 of the paper I attempt to answer the first question. In other words, I attempt to defend and explain the belief that we can use necessary features of international law to say meaningful things about global justice principles developed in isolation from those features.

In section 2 I give an example of a proposed global justice principle that fails to be compatible with the necessary features discussed in section 1. In doing so I begin to develop an account that explains which global justice problems require (explicitly or implicitly) international law for their solutions. Specifically, I discuss the problem raised by the principle of the moral equality of combatants in war. This principle, in its simplest form, states that "combatants do no wrong by simply fighting on the side lacking a just cause; that is, their moral status is prima facie equal to that of combatants fighting on the just side." The critics of this principle, like Jeff McMahan, David Rodin, and others, argue that the justice of the cause for a war affects the justice of fighting in such a war. ${ }^{3}$ This leads them to conclude that combatants on all sides of the conflict are not equally permitted to fight and that those on a side lacking a just cause have a moral responsibility to refuse to fight. I will argue that the implicative principle of inequality of combatants may not be institutionalized in international law because it fails to meet the rule of law conditions. My argument is not only meant to serve the practical purpose of answering applied questions about the justness of fighting in a war, but is also intended to act as support for my main claim about the appropriate role of

\footnotetext{
${ }^{3}$ Jeff McMahan, Killing in War (Oxford: Oxford University Press, 2009); C.A.J. Coady, "The Status of Combatants," in David Rodin and Henry Shue (eds.), Just and Unjust Warriors: The Moral and Legal Status of Soldiers (Oxford: Oxford University Press, 2008), chap. 8; David Rodin, "The Moral Inequality of Soldiers: Why jus in bello Asymmetry is Half Right,” in ibid., chap. 3.
} 
necessary features of international law-by showing how those features can be used in a discussion of some particular global justice dilemma.

\section{The International Law and the Rule of Law}

I believe that the necessary conditions of international law (the rule of law conditions) can and should be used as sifting tools for some proposed individual principles of global justice. ${ }^{4}$ To clarify this-my main claim-I start by giving a basic account of the notion of the "rule of law conditions," and I explain what it means to say that these conditions are necessary. This is meant to give us the building blocks to defend the claim that some of the time, when a proposed global justice norm is incompatible with the rule of law conditions, it fails to be a good norm of global justice (not simply of international law). This is obviously only true for those solutions for global justice problems that require governance and coordination via a system of rules for their accomplishment; but many proposed global justice norms are of this type.

\section{1.a. The international law and the rule of law conditions}

I start from two basic assumptions: first, that international law serves the purpose of governing human and state behavior and coordinating the efforts of local regulatory structures and individuals. And second, that to do so it needs to meet certain rule of law conditions. These, rather uncontroversially, require that legal rules be "clear, publicly accessible, stable, [capable of being followed], non-retrospective in content and application, and [that] official behavior be congruent with pre-existing legal norms." In making these assumptions, I am not saying that international law is the only way to govern behavior globally. I am simply claiming that if we want to govern behavior and coordinate our efforts

\footnotetext{
${ }^{4}$ By “individual principles of global justice,” I mean principles of justice dealing with individual problems that are global. I use the term "individual" to separate these principles from principles of global justice that are designed to answer general questions about global justice. So, for example, while a principle supporting a remedial right only for secession is an individual principle of global justice, the Rawlsian Law of Peoples is a general global justice principle.

${ }^{5}$ In "A Concise Guide to the Rule of Law," Brian Tamanaha calls these the minimal conditions for the rule of law (narrow conception), and suggests that they are accepted by everyone. Brian Z. Tamanaha, “A Concise Guide to the Rule of Law,” in Gianluggi Palombella and Neil Walker (eds.), Relocating the Rule of Law (Portland, Oregon: Hart Publishing, 2009), chap. 1. Obviously, this set of principles is even more commonly associated with Lon Fuller, but Tamanaha's paper is relevant for claiming that this trimmed-down version of rule of law conditions (trimmed down from both Fuller and Joseph Raz) is accepted by all or nearly all legal scholars.
} 
with respect to some goals via a system of rules, then that system needs to meet the rule of law conditions. I am also not assuming sovereignty. When I suggest that international law serves the purpose of governing the behavior of and coordinating between local regulatory structures, I am simply assuming a certain level of pluralism of aims and values, implying that at least some goals are best pursued locally and others globally. This justifies the claim that some governance of human and state behavior requires world-spanning legal structures.

International law, as it stands, is much more than this, but the argument I put forward concerns the features of international law that can be derived from these basic facts. I am not interested in how international law in its current state informs individual principles of global justice and attendant proposals for reform. Rather, I am only interested in how necessary elements of a world-spanning legal institution inform these principles and proposals for reform. I engage this sort of minimal account of international law in the hope that we can separate the features of international law that can justifiably be called upon in evaluating as well as building up principles of global justice from those that are temporary and are thus justly shunned by philosophers. I believe that the rule of law conditions are, in that sense, necessary features of international law and are among those that can be justifiably called upon in evaluating some proposed principles of global justice.

I am not suggesting that any and all proposed principles of global justice must pass the muster of being compatible with the rule of law conditions in the international context. Instead, what I am saying is that in some cases the incompatibility of a principle justified independently from institutional structures with those institutional structures is not a reason to change our institutional arrangements, but a reason to reject that principle. This most obviously holds true for those principles of global justice that require governance of behavior or coordination via a system of rules. For those sorts of situations for which governance of behavior via a system of rules is good (or necessary), rule of law conditions are reasons to be added to the balance of reasons in support of (institutional) acting one way rather than another in that situation. To illustrate this point, I will argue, in section 2, that fighting in war is one such situation.

My main point is that the rule of law conditions can and should act as sifting tools for separating good norms of global justice from poor ones. If we can show for some proposed individual principle that deals with a global justice problem that it is incompatible with the rule of law conditions, and if we can show that for that proposed principle governance of behavior and coordination via a system of rules is better (or necessary), then we have a good (or an overriding) reason not to act in accordance with that principle. 


\section{1.b. The rule of law conditions as necessary features of international law}

While there is near-consensus on some of the conditions that make up the rule of law, there is also broad disagreement with respect to the relationship between the rule of law conditions and the nature of law. The central debate raises two questions regarding the rule of law conditions: first, are they necessary for law to be law? And second, do they necessarily have a moral standing? The roots of this discussion can be found in the HartFuller debate. H.L.A. Hart argued against the belief that the rule of law conditions provide a path for claiming that there are moral standards in the very definition of law. ${ }^{6}$ On the other hand, Lon Fuller suggested that the rule of law conditions provide a type of internal morality that is definitive of the law. ${ }^{7}$ The positions on this issue vary greatly today: from those that argue that rule of law conditions are not, in fact, necessary for law to be law, to those that argue that they are necessary, but have no moral standing, to those that argue that they are both necessary and have a moral standing. In fact, each of these categories contains within it subcategories into which various legal and political theorists fit.

I cannot attempt to answer all the interesting and relevant questions regarding the rule of law conditions and the dilemmas associated with them. However, I must explain why I think one is justified in using the rule of law conditions to evaluate some proposed global justice norms, since this at a minimum commits me to a claim that rule of law conditions (in some sense) are necessary features of international law.

As I have mentioned, in relatively broad terms so far, I believe that solutions to some global justice problems require either by definition or by their proposed solutions governance of behavior via a system of rules. For international law (or any set of rules) to meaningfully govern human and state behavior, it must have certain features. Those are the "rule of law features.” They include the claims of:

(i) Generality: "Laws must be general, specifying rules prohibiting or permitting behavior of certain kinds."

(ii) Publicity: "Laws must also be widely promulgated, or publicly accessible. Publicity of laws ensures citizens know what the law requires."

(iii) Non-retroactivity: "Laws should be prospective, specifying how individuals ought to behave in the future rather than prohibiting behavior that occurred in the past."

\footnotetext{
${ }^{6}$ H.L.A. Hart, The Concept of Law (Oxford: Oxford University Press, 1961).

${ }^{7}$ For inconsistencies in Hart's response and possible solutions to them, see Jeremy Waldron, "Positivism and Legality: Hart's Equivocal Response to Fuller," New York University Law Review 83 (2008): 1135-69.
} 
(iv) Clarity: "Laws must be clear. Citizens should be able to identify what the laws prohibit, permit, or require."

(v) Non-contradiction: "Laws must be non-contradictory. One law cannot prohibit what another law permits."

(vi) Followability: "Laws must not ask the impossible."

(vii) Constancy: "[Laws should not] change frequently; the demands laws make on citizens should remain relatively constant."

(viii) Congruity: "Finally, there should be congruence between what written statutes declare and how officials enforce those statutes. So, for example, congruence requires lawmakers to pass only laws that will be enforced, and requires officials to enforce no more than is required by the laws."

These eight conditions, according to Fuller and many others, are "necessary conditions for the activities of lawmakers to count as lawmaking." Each one of them plays a role in the ability of the set of rules to govern human and state behavior. However, whether successful governing of human behavior is necessary for international law (or law for that matter) is, as I already mentioned, a very difficult question.

There is no doubt that something that fails all the rule of law conditions will fail to be a law. Even positivists like Hart believe that at least some of these conditions (for example, the condition of generality) have the standing of an analytically necessary condition. ${ }^{10}$ Similarly, failing to promulgate a rule seems like a good reason to say that that rule is no law. If the rule of law conditions are truly necessary for coordinating human behavior, and if governing human behavior is truly the hallmark of being law, then the rule of law conditions are necessary conditions for something being a law. However, some of the rule of law conditions truly

\footnotetext{
${ }^{8}$ Colleen Murphy, "Lon Fuller and the Moral Value of the Rule of Law," Law and Philosophy 24 (2005): 239-62. Murphy builds this account of the rule of law conditions from Lon Fuller and various restatements of his position. See Lon L. Fuller, The Morality of Law, rev. ed. (New Haven: Yale University Press, 1969); Jeremy Waldron, "Why Law? Efficacy, Freedom, or Fidelity?” Law and Philosophy 13 (1994): 259-84; David Luban, "Natural Law as Professional Ethics: A Reading of Fuller," Social Philosophy and Policy 18 (2001): 176-205; and Gerald J. Postema, "Implicit Law," Law and Philosophy 13 (1994): 361-87.

${ }^{9}$ Murphy, "Lon Fuller and the Moral Value of the Rule of Law," p. 241.

${ }^{10}$ Waldron, "Positivism and Legality,” p. 1152. Waldron quotes H.L.A. Hart: "what is in fact involved in any method of social control ... which consists primarily of general standards of conduct communicated to classes of persons, who are then expected to understand and conform to the rules without further official direction. If social control of this sort is to function, the rules must satisfy certain conditions: they must be intelligible and within the capacity of most to obey and in general they must not be retrospective, though exceptionally they may be.” H.L.A. Hart, The Concept of Law, 2nd ed. (Oxford: Clarendon Press, 1994), pp. 206-7.
} 
seem to be necessary only for governing human and state behavior well, and in that sense they seem like conditions for being a good or effective law rather than simply conditions for being a law. This is all further confused by the way "good law" is understood.

In one sense, something might meet the conditions of being a "good law" insofar as it meets the conditions necessary for it to be law. Or, put differently, something might be considered a good law inasmuch as it can (effectively) govern human behavior. In another sense, something might be a "good law" in the sense that it aims at some good, like peace or protection of some human right. In this sense we can have a law that is "doubly good," since it both pursues something worthwhile and is good in doing so. These two notions of "goodness" are separate, and it is the second of the two notions that is required to argue that law and morality have a necessary connection.

Scholars like Lon Fuller, John Finnis, and even Joseph Raz seem to think that the presence of the rule of law conditions doesn't simply mean that the law is good at governing human behavior. These scholars argue that laws that meet rule of law conditions are more likely to aim at an external good. ${ }^{11}$ For example, some of them would argue that the rule of law conditions of clarity and generality insure fairness, and that that in itself is good. A similar position held by some is that a society whose laws meet the rule of law conditions is likely to also be a "just society." It is in one of these two ways (internal morality or likelihood of pursuing "the good") that these scholars believe that the rule of law conditions guarantee a necessary relationship between law and morality.

These and many other issues complicate the discussion of whether rule of law conditions are necessary for law to be law, and whether they imply a necessary relationship between morality and law. One way out of this predicament is to propose that the rule of law conditions have various dimensions and that it is in one of their dimensions that they act like the necessary conditions for law and that it is in another dimension that they might ensure a more just society. Jeremy Waldron suggests this when he says:

Even if the same principle of legality [rule of law condition] is both tied to law and accorded moral significance, there is the further question of whether the ways in which it is tied to law match up with-or indeed literally are - the ways in which it is morally significant ... [one can imagine that] ... [a] Generality is criterially connected with law inasmuch as law cannot practicably operate without general rules. Our concept of a legal system must be the concept of a system that can work, and without general rules a legal

\footnotetext{
${ }^{11}$ Fuller, The Morality of Law; John Finnis, Natural Law and Natural Rights (Oxford: Oxford University Press, 1980); Joseph Raz, "The Rule of Law and its Virtue," in The Authority of Law: Essays on Law and Morality (Oxford: Oxford University Press, 1979), chap. 11.
} 
system cannot work ... [b] Generality tends to make a positive moral difference to a system of rule inasmuch as it associates law with something like Kantian universalizability. $^{12}$

The appeal of this proposal is that it allows for the most basic principle of positivism-the separability thesis (the thesis that there is no necessary connection between morality and law). This proposal also tries to explain why it is intuitively appealing to think that the rule of law conditions have moral significance. This view suggests that it is possible that a rule meets all the rule of law conditions and still fails to aim at something morally good.

An observation closely related to Waldron's point is key to the way I use the notion of necessity in my main claim. Consider the ways a law can fail a rule of law condition: a rule may fail to be promulgated at all (as in when a sovereign forgets to announce an intended law verbally or in writing), or it can fail to be promulgated well (as in when the majority of citizens that are subject to the law have not been informed about the requirements of a new law). In the first case, the proposed rule is, I believe, no law. In the second case, the proposed rule is a bad law. While it is not "bad" in a moral sense, it is "bad" because it cannot effectively govern human behavior. It is in the first sense that the rule of law condition of promulgation is an analytically necessary condition; it is in that sense that it needs to be met for law to be law. It is in the second sense that the rule of law condition is an instrumentally necessary condition; it is necessary in the sense that law cannot govern human behavior effectively if it is not met.

Similar examples can be given for other rule of law conditions. Consider the clarity condition. A proposed rule may fail to be clear at all, as in the following rule "the retro-mindedness of propagation is prohibited to all pottery masters of yesterday." Or it may fail to be fully clear, as in the case of the rule "prohibiting men from marrying." 13 In the first case, the rule fails to be a law since it cannot govern human behavior. In the second case, the rule fails to be a good or effective law since it cannot govern human behavior well. So then it seems that the rule of law conditions really have two dimensions - or two ways of being understood. In one way of understanding them, the conditions truly are necessary in the analytic sense. In the second way of understanding them, the conditions are instrumentally (or functionally) necessary. Incompatibility with the rule of law conditions in either of the two senses is bad for a proposed rule of global justice. In one sense, the incompatibility of a proposed rule

\footnotetext{
${ }^{12}$ Waldron, "Positivism and Legality,” p. 1166.

${ }^{13}$ “Prohibiting men from marrying” is ambiguous between "prohibiting men from marrying women" and "prohibiting men from marrying each other."
} 
with the rule of law conditions makes that rule unable to find expression through any system of rules; in another sense, incompatibility of a proposed rule with the rule of law conditions makes that rule a bad rule, an ineffective rule. In both cases the proposed rule ought to be rejected as law and even as a global justice principle (if such a principle requires implementation via a system of rules). So for my purposes, then, it does not matter whether the rule of law conditions are analytically or instrumentally necessary for law; incompatibility with such rules makes a proposed principle of global justice a bad one. ${ }^{14}$

An incompatibility of a proposed principle of global justice with some rule of law condition(s) makes that principle incapable of finding direct or indirect expression in international law or any system of rules comparable to international law. In a case in which one can give a separate normative argument for why such a global justice problem requires international law for its solution, this incompatibility with the rule of law conditions becomes a reason to consider the proposed solution/principle a poor solution to the problem (a poor global justice principle).

\section{The Principle of the Moral Equality of Combatants and Its Critics}

Jeff McMahan, David Rodin, Tony Coady, Henry Shue, and quite a few other scholars have recently been a part of an evolving debate regarding the principle of the moral equality of combatants (MEC). In its simplest form, MEC states that combatants fighting in an unjust war do not do anything wrong simply in virtue of fighting in that war, and thus combatants on all sides are prima facie moral equals. ${ }^{15}$ This principle is firmly grounded in international relations and is supported by some just war theorists. Just war theories, like that of Michael Walzer, have a built-in commitment to the moral equality of combatants. This position stems most commonly from the belief in the separation of jus ad bellum (justice of war) and jus in bello (justice in war) principles. Simply put, for the classical just war theorist, the justness of fighting in a war is independent of the justness of entering the war, allowing for the possibility that a

\footnotetext{
${ }^{14}$ Once again, "in cases when the global justice problem for which the proposed principle is a solution requires a system of rules for its implementation."

${ }^{15}$ McMahan, Killing in War; Jeff McMahan, "Laws of War," in Samantha Besson and John Tasioulas (eds.), The Philosophy of International Law (Oxford: Oxford University Press, 2010), chap. 24; Jeff McMahan, “The Morality of War and the Law of War,” in Rodin and Shue (eds.), Just and Unjust Warriors, chap. 2; Henry Shue, "Do We Need a 'Morality of War'?” in ibid., chap. 5; Rodin, “The Moral Inequality of Soldiers”; Coady, “The Status of Combatants”; Larry May, War Crimes and Just War (Cambridge: Cambridge University Press, 2007). Others include Darrel Moellendorf, Lionel McPherson, Seth Lazar, Christopher Kutz, and probably many more.
} 
combatant lacking a just cause for war might nonetheless fight that war justly. Many scholars have recently criticized the principle of moral equality of combatants, and have instead argued for what I will call a principle of inequality of combatants (PIC). PIC asserts that combatants whose side is lacking a just cause are not justified in fighting in the war. I believe that these scholars are right in believing that a soldier who lacks a just cause has strong reasons not to fight in a war; however, I think they are wrong in suggesting that this implies that PIC can or ought to be a law or a global justice principle (principle of behavior for global institutions). I believe that appealing to the rule of law conditions and a set of necessary facts about our world is sufficient to show that PIC cannot be a principle of global justice or international law.

One of the most complete arguments against the moral equality of combatants (MEC) comes from Jeff McMahan in his recent book Killing in War. McMahan's basic intuition behind this criticism of MEC is grounded in a continuity of application of principles of ordinary morality to the state of war. He wants to discredit the "common sense" belief that once the term "war" is applied to a set of circumstances a different set of moral principles applies, especially with regard to killing. He hopes that showing this would in turn show that, in general, there is no moral equality of combatants in war.

McMahan grounds his argument in the notion of liability, a central pillar of the classical arguments for the moral equality of combatants. The classical position has it that fighters on all sides present a threat and a danger, and this makes them liable to attack. In other words, the classical just war theorist argues that posing a threat to the soldiers on the opposing side constitutes sufficient reason for the loss of the right not to be attacked. But McMahan argues that being a threat is not and cannot be sufficient for one to be a legitimate target in war, that is, it is not sufficient for becoming liable to attack. Consider, for example, a murderer of ten innocent people shooting at police who have come to stop him. This murderer cannot argue that the police have made themselves liable to attack by simply being a threat to him. In other words, being a threat when you are justified in being one does not make you liable to attack. Instead, McMahan proposes that "the criterion of liability to attack in war is a moral responsibility for a wrongful threat," which is "a threat of wrongful harm - that is harm to which a victim is not liable-posed by action that is objectively wrong."16

With a notion of liability in hand, which rests not on threat of harm, but on wrongful threat of harm, McMahan argues (contrary to current policy and classical just war theory) that it is almost impossible for un-

\footnotetext{
${ }^{16}$ McMahan, Killing in War, p. 38.
} 
just combatants to fight a war justly. ${ }^{17}$ It is impossible for them to do so because combatants on the side lacking a just cause will almost always fail both the jus in bello condition of discrimination and the condition of proportionality.

The jus in bello condition of discrimination requires that one does not attack illegitimate targets. Since combatants on the just side have a right to be a threat, they do not make themselves liable to attack and thus are not legitimate targets. This implies that except in very rare circumstances, unjust combatants (those fighting for an unjust cause) do injustice when they kill the combatants on the opposing side, if that side is just.

The case for proportionality is significantly more complex, but taking the notion of liability to be central to the definition of proportionality, McMahan argues that the unjust combatants' actions cannot be proportionate since they "cannot have good effects of the appropriate sort that would be sufficient to outweigh (1) the intended harms to just combatants, (2) the harms caused to innocent people as a side-effect, and (3) the unjust intended ends."18

Ultimately, McMahan's argument simpliciter relies on the claim that the notion of liability is misunderstood in classical just war theory, international law, and on the streets of most of our nations, and that there is no discontinuity between the notion of liability in individual cases and in war. Because of that, unjust combatants are almost never able to fight the war justly, and thus MEC is false. His argument presents support for PIC, or what others have called the "asymmetry principle."

McMahan's argument against MEC, obviously, doesn't embody the views of all the scholars who have recently rejected MEC. However, inasmuch as it relies on a "corrected" understanding of liability to harm, it shares their basic intuition. David Rodin, for example, agrees that soldiers can be held responsible for fighting in an unjust war, and that "it would seem that a long-standing tenet of Just War Theory must be abandoned-soldiers fighting an unjust war have no permission to kill, and there is no 'moral equality' between soldiers."19 He also argues that neither consent-based arguments nor duress-based arguments are sufficient to justify a right to kill for soldiers lacking a just cause. But in contrast to McMahan, Rodin does not believe that accepting the asymmetry view that says that unjust combatants may not kill just combatants, though just combatants may kill unjust combatants, also entails an acceptance of the

\footnotetext{
${ }^{17}$ Ibid., p. 42.

${ }^{18} \mathrm{I}$ am grateful to an anonymous reviewer for this phrasing of the issue.

${ }^{19}$ David Rodin, War and Self-Defense (Oxford: Oxford University Press, 2003), p. 173.
} 
extended permission for just combatants to kill civilians in certain cases. ${ }^{20}$

While there are quite a few further differences between McMahan and Rodin, they and others who have recently rejected MEC believe that soldiers lacking a just cause are wrong in fighting and killing in war, and thus that the principle of the moral equality of combatants is false. By turning to the analysis of policy implications of their views, I will explain why we need to decouple the arguments for whether or not a soldier ought to fight in an unjust war from arguments for how we (as a global community) ought to treat them via institutional and legal instruments and mechanisms.

\section{The Principle of Inequality of Combatants and International Legal Reform}

Separate from the arguments like the ones McMahan and Rodin give (above) are claims regarding what should be done in light of such arguments in the legal sphere. Ought we to have policies and laws that prohibit fighting for those soldiers who lack a just cause? Ought we to have penalties for fighting in an unjust war for ordinary soldiers, that is, should we criminalize such actions? In response to these questions, I argue that MEC's entrenchment in law is not accidental, but can in fact be justified by appeal to the rule of law conditions and their derivatives. Even those scholars who seem to acknowledge (to a smaller or greater extent) that MEC is a fixture of law seem nonetheless to think that the conditions that make equality of combatants a legal fact are temporary and not necessary facts of law, in general, and international law, in particular. I think they are wrong about the "temporary character" of the conditions that justify the equality of combatants as a legal principle. I argue that if a particular principle (like that of equality of combatants) must be accepted as international law, then the presence of that principle in law affects the plausibility of competing global justice principles. While global justice principles obviously ought to be informed by principles of individual ethics and ordinary morality, in this case, appealing to the rule of law conditions is sufficient to explain why positions embracing PIC ought not to be taken seriously as global justice principles or policy suggestions. I argue that PIC (a global justice principle of inequality of combatants) is not compatible with the necessary features of international law.

In "The Morality of War and the Law of War," McMahan argues that one reason we commonly accept MEC is its entrenchment in internation-

\footnotetext{
${ }^{20}$ Rodin, “The Moral Inequality of Soldiers.” I am grateful to an anonymous reviewer for the phrasing here.
} 
al law coupled with the mistaken conflation of law and morality, especially in the realm of international law. He suggests that we have, in the realm of global justice, suffered from an inversion of the "normal" relationship between morality and law, and have mistakenly allowed international law to inform morality. But even though he believes MEC is false, he is wary of simply suggesting that we ought to have asymmetrical laws of conduct in war. In fact, he acknowledges that "this correspondence with morality does not and, at present, cannot hold in the case of the international law of war." ${ }^{21}$ He thinks this is the case for a variety of pragmatic reasons. These reasons that give rise to the entrenchment of the legal equality of combatants include: epistemic limitations of soldiers, rationalizations of justness of fighting among the unjust combatants, the resulting fact that that which is permitted to the just will be done by the unjust, the fact that prosecuting unjust combatants might prolong war, and so on. ${ }^{22}$

Ultimately, McMahan thinks that "the legal equality of combatants is a fixture of the law and must remain so until we are able to alter the conditions that make it necessary." 23 He thinks we can do that, and address the practical concerns mentioned above, by having a philosophically minded and international jus ad bellum adjudication mechanism that is neutral and efficient. By having a jus ad bellum adjudicating mechanism that would be functional during or prior to conflict, he believes we can alter the conditions that give rise to the reasons that make equality of combatants a practical, legal necessity. Until that time; until we can change the laws, McMahan believes we ought to be committed to a twotier (moral-legal) system of conduct in war in which the two sets of rules diverge.

McMahan believes we could have a court-like jus ad bellum adjudicating institution (made up of experts in the relevant fields) whose primary goal would not be punishing unjust combatants, but providing them with epistemic guidance. ${ }^{24}$ In his "Prevention of Unjust Wars," McMahan starts from the assumption that the doctrine behind the Permissibility of Participation (MEC) is “wholly incredible.” But he rightly separates that

\footnotetext{
${ }^{21}$ McMahan, “The Morality of War and the Law of War,” p. 19 (my emphasis).

${ }^{22}$ It is "pragmatic considerations [that] force us to forgo the possibility of criminalizing participation in an unjust war." McMahan, "The Morality of War and the Law of War," p. 29.

${ }^{23}$ McMahan, Killing in War, pp. 109-10.

${ }^{24}$ Jeff McMahan, “The Prevention of Unjust Wars,” in Yitzhak Benbaji and Naomi Sussman (eds.), Reading Walzer (London: Routledge, 2012, in press). In this paper, McMahan discusses what he calls the doctrine of the "Permissibility of Participation." It is worth noting that PIC and MEC are principles that, conceptually speaking, rely on the relationship between the moral status of combatants in a war, while the Permissibility of Participation does not.
} 
issue from the issue of consequences of a widespread rejection of that doctrine. Accordingly, he argues that some sort of mechanism is necessary to provide epistemic guidance with respect to justness of the war in a world in which we acknowledge that it is not permissible to fight in an unjust war. He believes having such a mechanism is both possible and desirable, but argues that for the foreseeable future such a mechanism would have to be extra-legal. ${ }^{25}$

In contrast to McMahan, Henry Shue argues against the assumption that we must extend ordinary morality to morality of war. $^{26}$ In fact, he argues, in line with Walzer, that attempting to do that would be like giving "a careful and precise account of what individual responsibility in war would be like if war were a peacetime activity." ${ }^{27}$ His basic intuition seems to be that the extension of the notion of liability from individual ethics to war is flawed exactly because the practice of war is already so morally deviant. Shue is, further, concerned with the usefulness of having rules or laws that would be directed at unjust soldiers in an environment in which most soldiers believe they are just. He argues that war is a horrible thing, but the key is having rules and laws that would govern fighting in war effectively and in such a way so as to make it the least horrible it can be. Accordingly he argues that (a) there is, in fact, a relevant distinction between morality that applies in war and morality that applies in peace, and, more importantly, that (b) the two-tier suggestion of normativity where legal rules and moral rules stand in dissonance fails. ${ }^{28}$ Specifically, Shue suggests that "where the laws of war are morally justified, there is no function to be performed by a competing 'morality of war' consisting of alternative rules." 29

But for all their disagreement, Shue and McMahan seem to agree that at least "at present" we cannot have laws of war that embrace PIC. ${ }^{30}$ Rodin, however, disagrees. He rejects both McMahan's and Shue's solutions to the dilemma regarding bringing the laws of war into conformity with the ordinary morality of war. He rejects the view that laws of war cannot be brought into alignment with the morality of war because of "highly damaging consequences" (McMahan's view), as well as the view that ordinary morality and morality that applies in war are somehow dif-

\footnotetext{
${ }^{25}$ McMahan, “The Prevention of Unjust Wars.” See, e.g., section 2 on the enhanced understanding of a practical proposal, on enforcement, and on the inhospitable domain of international law.

${ }^{26}$ Shue, “Do We Need a 'Morality of War'?”

${ }^{27}$ Ibid.

${ }^{28}$ Henry Shue, "Laws of War," in Besson and Tasioulas (eds.), The Philosophy of International Law," chap. 25, and “Do We Need a 'Morality of War'?”

${ }^{29}$ Shue, “Do We Need a 'Morality of War'?” p. 89.

${ }^{30}$ Of course, Shue thinks we shouldn't have such laws, but that is consistent with the view that "at present" we ought not have or cannot have such laws.
} 
ferent (Shue's view). ${ }^{31}$ Specifically he argues that we can and ought to have laws that prohibit fighting to soldiers lacking a just cause, and furthermore that we ought to have criminal penalties for such behavior. Rodin acknowledges that the asymmetry thesis (PIC) seems quite implausible to many, in part because of their conflict with the current Laws of Armed Conduct (LOAC), but he believes that if the asymmetry thesis is understood as only prohibiting fighting and killing for the unjust combatants, and not at the same time extending privileges to the just combatants, the asymmetry principle becomes much more palatable and enforceable via law. In fact, he thinks that we have "no alternative" but to implement the asymmetry principle in legal practice as well. For Rodin, claiming that the ordinary morality somehow doesn't apply in war simply because it is war (a suggestion akin to Shue) is plainly wrong. He thinks that ordinary morality and minimal claims of human rights are the unavoidable building blocks of all our moral norms in all spheres of action (ordinary or not).

It seems to me, however, that Rodin misses the point to some extent. Of course human rights apply in cases of war; they really are the building blocks of moral norms. But moral norms can also be limited by other considerations. Shue thinks the type of activity that war is is one such consideration. He seems to think that meeting the duties that minimal human rights impose on us in times of war can best be accomplished by embracing laws that symmetrically limit fighting in war. I, for example, think that the structural and procedural limitations of institutions that are supposed to implement and protect minimal human rights also limit what sorts of norms we may have (as a global society). Simply put, I believe that if discharging a duty concomitant to some basic human right requires an institution, and if that institution necessarily limits the ways we discharge that duty, then understanding what minimal human rights require of us depends on understanding the necessary features of that institution. Rodin's position embodies my original concerns about building global justice principles in isolation from institutions that are supposed to implement them, about informing such principles simply by what human rights require.

Global justice norms are, on my view, formed by our best moral practices (i.e., rules of ordinary morality) and structural demands of institutions that are supposed to implement them. This is why I think we must decouple the view that unjust soldiers ought not to fight from the view that we ought to somehow treat them differently via global institutions. I believe that the laws of war and ordinary morality cannot be brought into

\footnotetext{
${ }^{31}$ David Rodin, "Morality and Law in War," in Hew Strachan and Sibylle Scheipers (eds.), The Changing Character of War (Oxford: Oxford University Press, 2011), chap. 24.
} 
conformity ever (contrary to McMahan), not because war is such a unique and destructive practice (contrary to Shue), but because the rule of law conditions require that the laws of war be addressed to combatants, rather than to unjust or just combatants.

\section{Why the Principle of Inequality of Combatants Cannot Be an International Law or a Good Principle of Global Justice}

I believe we cannot have PIC laws-jus in bello laws treating just and unjust combatants differently, namely, laws prohibiting fighting for unjust combatants-because such laws would be incompatible with necessary conditions of international law, namely, the rule of law conditions. PIC laws might meet rule of law conditions if we could legislate open access to all relevant information or if we had adjudication mechanisms for justness of cause. But we can neither legislate open access to all relevant information, nor can we have adjudication mechanisms that would justify PIC laws, that is, adjudication mechanisms that would occur on timescales that would allow for PIC laws to overcome their incompatibility with the rule of law conditions.

My argument suggests that the rule of law conditions of clarity and followability make it so that we may not have laws requiring actions of a group of people without knowing who belongs in that group of people. Some of the time, knowing who is subject to a particular law requires adjudication. I believe that directing different laws of armed conduct at just and unjust combatants requires adjudication. In other words, we cannot have laws treating soldiers differently based on whether the cause they are fighting for is just without having a well-functioning body to adjudicate justness of the cause. However, I do not think we can have such an adjudication mechanism-one that would be able to adjudicate justness of cause for war in such a way so as to be able to inform combatants which set of laws both applies to them (just or unjust) and meets the rule of law conditions. It is important to note that I am not saying we cannot have adjudication mechanisms for justness of cause, but that we cannot have adjudication mechanisms for justness of cause that could justify having separate laws of armed conduct for just and unjust combatants while meeting the rule of law conditions.

To start, I explain why I think we must have an adjudicating mechanism for justness of the cause for war so as to be able to justify having different jus in bello laws for just and unjust combatants, that is, so as to have PIC laws be compatible with the rule of law conditions. Consider an analogy between, on the one hand, laws governing individual selfdefense and laws governing assault, and, on the other hand, laws governing conduct of just and conduct of unjust combatants. Obviously, shoot- 
ing at a person prima facie constitutes assault, but shooting at an attacker counts as self-defense and is subject to a different set of regulations. Obviously there are still limitations on what one might do in self-defensefor example, one may not shoot at an arthritic senior coming at one with a butter knife. But the key point is that laws that apply to a shooter and to a shooter acting in self-defense are different. Obviously, we do not need to (legally) adjudicate whether the situation has a just cause before the person engaging in self-defense is justified in fighting back. ${ }^{32}$ This seems obvious, but I argue that it is only obvious in the case of individual selfdefense. In cases of self-defense, the knowledge required with respect to just cause for an individual is minimal. In cases of just war, the knowledge required is immense. In fact it is so large in scope and so specialized in type that the analogy fails. The scope and type of knowledge needed to evaluate the justness of a cause for war are so large and specific that the rule of law conditions of clarity and followability preclude legislating of any rule that would require individuals to act based on whether their side has or lacks such a cause. ${ }^{33}$ Simply put, rule of law conditions require that we do not have laws that cannot be followed. Any rule that would ask people to behave in a particular way depending on whether they belong in a set whose membership criteria are not readily knowable fails the rule of law conditions.

In fact, it is not only that we are expecting soldiers to evaluate the justness of the cause, but we are expecting them to evaluate both the justness of the cause and possibly even the intentions behind their leader's decisions to engage in a conflict. ${ }^{34}$ So not only are we requiring specialist knowledge with respect to a conflict or a region or history or economic factors or law, or even sensitive information, but in proposing PIC laws (without an adjudication mechanism for justness of cause) we would be some of the time requiring combatants to assess the intentions behind their leaders' decisions to enter a war. And that seems unreasona-

\footnotetext{
${ }^{32}$ Here I mean that an individual acting in self-defense need not submit a petition to the court prior to being justified in engaging in self-defense (such a petition is not constitutive of justification for fighting back).

${ }^{33}$ Unless we had adjudication of justness of the cause prior to engagement, but I have already argued against this.

${ }^{34}$ Some scholars might suggest that "whether a jus ad bellum court would consider a leader's intentions in fighting a war is not [decisively] relevant to the determination of whether it was permissible for that leader's soldiers to fight in that war. The correct view may well be that while it is wrong for the leader to initiate a war with wrongful intentions, it could nevertheless be permissible for soldiers to fight in that war if it met the objective conditions of permissibility and their own intentions in fighting it were acceptable.” I am grateful to a reviewer for Social Theory and Practice for this phrasing of the issue. I disagree that a war that was started with primarily wrongful intentions can in fact be permissible. I argue this point more extensively in "The Role of Right Intentions in Humanitarian Military Interventions,” M.A. Thesis, University of Maine, 2004.
} 
ble. This seems to be expecting significantly more than asking a victim of an assault to evaluate whether the attacker is in fact trying to hug her while holding a knife, or actually trying to harm her.

Evaluating the justness of a cause for war and the intentions behind our leader's decisions with respect to that war requires specialist knowledge as well as special access to information that international law must provide if it is to require action based on it. International law cannot provide such direct access to knowledge, at a minimum because of timescales on which conflict occurs, but also because of the type of sensitive information that is sometimes required for such knowledge. The rule of law conditions of clarity and followability then prohibit imposing any such rules, just as they would prohibit imposing rules based on a presence of a gene (without a phenotypic expression) in an individual. Unless a law was able to legislate "open access" to genetic testing, such a law would be prohibited by rule of law conditions. I take it that international law cannot legislate any open access to all relevant information, nor can it legislate a sufficient level of time before conflict for soldiers to evaluate all the relevant data, nor can it legislate access to education required for combatants to be able to interpret the information, and so on.

Ultimately, I am arguing that there is a legal principle derivable from basic rule of law conditions, which says that a rule that requires actions of a particular kind from certain actors, whose being subject to that law is dependent on knowledge they cannot reasonably be expected to have, fails the rule of law conditions of clarity and followability. To further illustrate, consider laws against trespassing on land. An act of being on land owned by someone else is only trespassing if such an act is intentional (U.S. law) or negligent (British courts). This implicitly requires that there be signs or fencing or some obvious way for an individual to know that she is trespassing. This is because it would be unreasonable to require the knowledge about ownership of each and every parcel of land. So then, when the knowledge required to judge whether one is subject to a particular law is such that people cannot be reasonably expected to have it, suggesting laws based on such knowledge fails the rule of law condition of clarity and followability. This is why the rule of law conditions require that we have ad bellum adjudicating mechanisms to justify having PIC laws (laws treating just and unjust combatants differently). But these adjudicating mechanisms cannot be of just any kind: they need to be able to inform combatants of limitations on their armed conduct in a way that is fair and effective.

This position, that having adjudication mechanisms with respect to justness of cause for war could justify having separate laws of conduct for just and unjust combatants, can be understood in three ways. First, one could propose that we ought to have adjudication of the cause prior 
to the start of the conflict, and that if and only if such adjudication is completed prior to the beginning of the conflict with respect to the cause claimed at the beginning of the conflict, we may apply different laws to those with and without a just cause. On this view no one would be justified in fighting until the justness of their cause was adjudicated. A second option is to say that there simply are two sets of laws applying to just and unjust combatants, regardless of whether the adjudication of cause happens prior to, during, or after the conflict. I take this to be the most common view with respect to this proposal. Third, one could argue that we can have separate laws for just and unjust combatants, but that they would only be applicable if and when we adjudicate. So, on this view, one set of laws - that for just combatants-would apply to all until adjudication was completed, and after such adjudication a different set of laws would apply to the actions of unjust and just combatants. Note that, in a way, this is an instance of the first proposal.

With respect to the first proposal, obviously we cannot require adjudication of the just cause prior to conflict as a condition for fighting in war. This would be a problem since, if adjudication were required in order to be allowed to fight in a war, those with a just cause would, for example, not be able to engage in self-defense. On the other hand, if this proposal were understood not as "making" the warring sides wait for a decision by a court, but as requiring adjudication on timescales on which wars start, then it would be simply the limits of space and time that would prevent us from ever having such adjudicating mechanisms. Note that I am not simply arguing that it is impossible that the international court could have adjudication mechanisms with respect to jus ad bellum. After all, at a recent conference on the International Criminal Court (ICC) in Kampala, Uganda, a tentative agreement seems to have been struck for jurisdiction of the International Criminal Court in cases of aggression. ${ }^{35}$ Instead, I am arguing that such adjudication cannot plausibly take place prior to a conflict, nor can it inform laws of conduct in war. But I do not think that many scholars would in fact propose a requirement that we adjudicate the cause prior to anyone being justified in fighting.

The second proposal is that we have asymmetrical laws regarding conduct in war, whose applicability would not depend on when such adjudication occurred. On this view, we would be justified in applying a separate set of laws to combatants who were on the unjust side. This argument in support of PIC laws might go on to say that these sorts of (PIC) laws could further deter combatants from fighting in unjust wars

\footnotetext{
${ }^{35}$ Kampala, Uganda meeting on the future of the ICC, June 2010. The proposed legislation would extend the ICC jurisdiction over wars that constitute aggression-in the sense that they breach the United Nations charter, or lack justification or authority.
} 
by threatening prosecutions to those who were in fact on the unjust side. The laws governing how just combatants ought to act might still have all sorts of prohibitions against killing civilians, and the laws governing how unjust combatants ought to fight would prohibit close to everything. This proposal would fail for many of the same reasons I give above-it would require actions of subjects without consistently giving guidance as to who they (the subjects) are. That would seem to patently break the rule of law condition of followability and clarity.

Finally, then, we turn to the third proposal-a proposal that would avoid the problems of the first two. On this view, due to all the reasons I have so far suggested, there would be one set of laws applying to all combatants at the beginning of the war, and another set of laws that would apply to combatants differently depending on the justness of their cause, after the justness of the cause had been adjudicated. I think this suggestion is problematic as well. First, we would still ultimately have MEC-type laws operating during most of the conflict and for most conflicts. Second, such laws would give a perverse incentive to annihilate the opponent as swiftly as possible, and through any means necessary, prior to adjudication of cause. Third, in most cases this adjudication would either have no effect on the war or it would be unfair (due to its speediness). Fourth, the dependence of change in applicable laws on time of adjudication would seem to result in grossly unfair treatment of unjust combatants. In some wars that are swift, the combatants without a just cause would be justified in fighting, and in those that took longer for any reason, the unjust combatants would more likely be prohibited from fighting in a middle of a war. Fifth, it is becoming widely accepted that the idea that there is a single, unchanging cause for war operating on each side is false. This is most importantly also accepted, in fact especially suggested and welcomed, by the same group of scholars who might support PIC. These same scholars (including McMahan and Rodin) are, rightly, acknowledging the fact that causes (and intentions), and thus justness of the same, shift throughout the war. So while a nation might enter a war for one reason or another, in almost every case, the causes behind the war and the intentions behind the fighting (its aims) shift all the time. There is then a serious confusion regarding applying different laws based on presence of a cause or intention a year ago, which might be lacking now.

Ultimately, it seems to me that all three proposals for adjudication mechanisms that could justify having PIC laws fail. These same reasons that suggest PIC may not be an international legal principle are also reasons to claim that the equality of combatants ought to be. International law must embrace the principle of equality of combatants, in part, because it must have rules that govern fighting in war if it is to be effective. 
After all, one of the few things that an international regulatory structure is most obviously needed for, and preferable over local regulatory structures for, is regulating conflict. In a world of uncertainty with respect to justness of a cause for war and the right intentions of the warring sides, to embrace the principle of equality of combatants is to choose an option that is enforceable and attempts to protect the civilians while allowing the just to fight. Contrary to scholars like McMahan, I have argued that the underlying principles behind the rejection of PIC as a legal norm are necessary, not temporary, features of international law. They are not features of an institution that is "still in its infancy," and "depends on its authority on the consent of states." ${ }^{\text {, Th }}$ They are, I have argued, features of any properly international and properly legal institution.

But what does all this mean, if anything, for the moral argument against the equality of combatants? So far we have shown that the principle of combatant inequality cannot be legally justified. I believe that if I am right that PIC may not be law and MEC must be, we have a good reason to say that even though there are some good arguments against the permissibility of fighting in an unjust war, they are not (good) arguments for what we as a global society ought to do with that. Arguments that address the question of what we (the global society) ought to do with some global justice problem (like that of unjust soldiers) must be partially (and in this case I think conclusively) informed by structural and procedural facts about necessary institutions available for the pursuit of justice.

We ought to distinguish between individual principles of morality, which address individuals, principles of global justice, which address institutional responses, and principles of international law, which address international and legal responses. I have argued that in the case of the principle of inequality of combatants (PIC) we have reasons grounded in necessary features of international law to reject this principle as a legal tool. But I have also attempted to give some reasons to think that the most coherent and most responsible response we (as a global society via institutions) can give to armed conflict is the legal response. This is why showing that PIC ought not to be a law is also showing that it is not a good principle of global justice (i.e., principle of action for a global society via institutions). ${ }^{37}$

\footnotetext{
${ }^{36}$ McMahan, “The Prevention of Unjust Wars,” section 2.

${ }^{37}$ Some scholars, in particular McMahan, have argued that we could have a extralegal court-like institution mandated with providing epistemic guidance to combatants regarding the justness of their wars. I think that any such proposals, including McMahan's detailed sketch of one, are likely to fall prey to some of the same rule of law incompatibility as they approach better functioning. In other words, it seems to me that the more court-like such an institution is, the more it will be useful in providing guidance to combatants, but also the more likely it is to fail to meet rule of law conditions that increase the epistemic certainty and authority of such determinations.
} 
This analysis is further helpful inasmuch as it redirects our efforts to put into practice the intuition that it would be better if unjust combatants did not fight. Showing that PIC may not be international law might give us extra reasons to think that we ought to instead have domestic laws that permit conscientious objection on a war-by-war basis. ${ }^{38}$

Ultimately, there are many questions one might ask with respect to fighting in an unjust war, but two central questions (which however related are nonetheless separate) are: what ought a soldier fighting in an unjust war do, and what principle ought we as the global community take up regarding those fighting in an unjust war? While I am not suggesting that the current Law of Armed Conflict is the best possible law, I am suggesting that what the morally best law of armed conflict can be is limited by functional features of international law in such a way that some form of the equality of combatants must be embraced by such law. ${ }^{39}$

Jovana Davidovic

Philosophy Department, University of Minnesota

and

Center for Applied Philosophy and Public Ethics, Charles Sturt University

david258@umn.edu

\footnotetext{
${ }^{38}$ Several scholars including Tony Coady have discussed this possibility.

${ }^{39}$ I wish to thank Sarah Holtman, Brian Bix, David Weissbrodt, Larry May, Tom Campbell, and Britt Johnson for written comments on earlier drafts of this paper. I am particularly indebted to Michelle Mason and Jeff McMahan for multiple sets of comments on multiple drafts of this paper. I have also benefited from comments from audiences at the CAPPE (Center for Applied Philosophy and Public Ethics) seminar at Australian National University, 2010, and at the Australian Legal Philosophy Society Conference, 2011.
} 